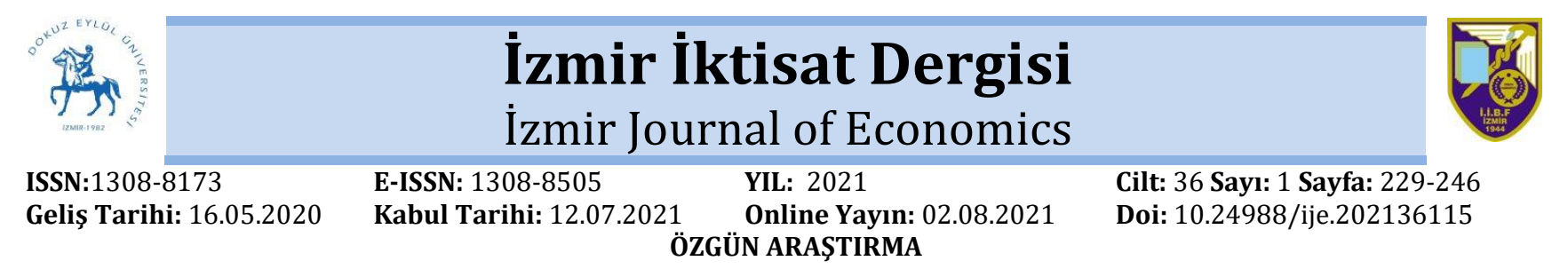

\title{
Ürün Uzayı Değişkenlerinin Türkiye İBBS Düzey 2 Bölgelerinde Büyüme Dinamiklerine Etkisi ${ }^{1}$
}

\author{
İsmail TUNCER ${ }^{2}$, Nuran COŞKUN ${ }^{3}$
}

\begin{abstract}
Özet
Neo-klasik büyüme modelinden hareketle ve üretken bilgi/beceri setinin teknolojiyi kaydıran faktör olduğu ve beklenen verimliilik seviyesinin girişimci sayısının artan bir fonksiyonu olduğu kabul edilerek türetilen büyüme modeli, Türkiye IBBSS Düzey-2 bölgeleri, 254 imalat sanayi sektörü ve 2004-2014 dönemi için sınanmıştır. Mekânsal etkileri ve dinamik yapıyı dikkate alan tahmincilerden elde edilen bulgulara göre, Ürün Uzayı yaklaşımı kullanılarak sanayi politikalarının belirlenmesi, Türkiye ekonomisinin kalıcı bir iktisadi büyüme süreci yakalanmasına hizmet edebilecektir. Devlete veya yerel kalkınma inisiyatiflerine düșen rol bölgelerin mevcut bilgi/beceri seti dâhilinde karşllaştırmalı üstünlüğe sahip olduğu verimliliği yüksek gizil/örtük sektörleri tespit ederek bu sektörleri önceleyen politika tedbirlerinin şekillendirilmesi olacaktır.
\end{abstract}

Anahtar kelimeler:Ürün Uzayı, Evrimci Ekonomik Coğrafya, Yeni Yapısalcı İktisat, İhracat Sofistikasyonu, Ekonomik Kompleksite, Dışsallıklar.

Jel Kodu: 01, 04, 025

\section{The Impact of Product Space Variables on Growth Dynamics in Turkey NUTS-2 Regions}

\begin{abstract}
Starting from a Neo-Classical growth model and assuming that productivity is an increasing function of entrepreneurs and productive knowledge/skill set is the technology shift parameter, a growth model has been derived and estimated for NUTS2 regions of the Turkish Economy with 254 manufacturing industries for the period of 2004-2014. The results obtained by using dynamic estimation methods that take into account the spatial effects indicated that, the method of product space can be used and has the potential to develop a permanent growth process in the Turkish Economy. Moreover, the government and the local development initiatives can play substantial role in designing regional industrial policies that promote latent/implicit industries with high productivity in which regions will gain comparative advantage given their current factor endowment.
\end{abstract}

Keywords: Product Space, Evolutionary Economic Georgraphy, New Structural Economics, Export Sophisticaiton Economic Complexity, Externalities.

Jel Codes: 01, 04, 025

\section{Gíriş}

Sanayi devrimi sonrası dönemde, zengin ülkeler hızla daha zengin hale gelirken, yoksul ülkelerin bazıları giderek daha yoksul hale gelmiştir. Dünyadaki bu ıraksama eğiliminin yanı sıra, yerküre üzerinde iki önemli yakınsama dalgasına tanık olunmuştur. Bunlardan ilki 1950-1960 döneminde Avrupa çevresinde diğeri ise 1960-1980 ylları arasında bazı Doğu Asya ülkeleri arasında yaşanmıştır. Bazı ülkeler zenginken, diğerlerinin neden yoksul olduğu sorusu iktisat biliminde büyüme ve kalkınma alanındaki en

ATIF ÖNERísi (APA): Tuncer, İ., Coşkun, N. (2021). Ürün Uzayı Değişkenlerinin Türkiye İBBS Düzey 2 Bölgelerinde Büyüme Dinamiklerine Etkisi. İzmir İktisat Dergisi. 35(1). 229-246. Doi: 10.24988/ije.202136115

\footnotetext{
${ }^{1}$ Bu çalıșma, Prof. Dr. İsmail TUNCER danışmanlığında yürütülen “Ürün Uzayı Yaklaşımı: Türkiye İBBS Düzey 2 Bölgeleri içim bir Uygulama" başlıklı doktora tezinden üretilmiştir.

2 Prof. Dr, Mersin Üniversitesi, İktisadi ve İdari Bilimler Fakültesi, Yenişehir/MERSİN,

EMAIL: ituncer@mersin.edu.tr ORCID:0000-0003-0180-7415

${ }^{3}$ Araş. Gör. Dr., Mersin Üniversitesi, İktisadi ve İdari Bilimler Fakültesi, Yenişehir/MERSìN,

EMAIL: ncoskun@mersin.edu.tr ORCID:0000-0002-7803-7968
} 


\section{TUNCER - N. COŞKUN}

temel sorulardandır. $\mathrm{Bu}$ soru cevaplandırılmaya çalıșılırken devasa bir büyüme ve kalkınma literatürü ortaya çıkmış, farklı disiplinlerden araştırmacılar bölgelerin büyüme ve kalkınma sürecini belirleyen unsurları araştırmaya çalışmıştır. İktisat teorisi ve kalkınma yazınındaki gelişmeler bağlamında, kalkınmak için gelişmekte olan ülkelere önerilen ve belli ölçülerde izlenen politikaların ortaya çıkardığı hayal kırıklıkları ile teorik alandaki farklı görüşlerin etkileşimi sonucu, son dönemde kalkınma alanında yeni bir akımın kendini gösterdiği görülmektedir. Aralarında Dani Rodrik, Ricardo Hausmann, Ann Harrison, Michael Spence ve Philippe Aghion, Justin Yifu Lin gibi iktisatçların yer aldığı ve "Yeni Yapısalcı İktisat" olarak adlandırılan bu akım; büyüme ve kalkınma çalışmalarının merkezine tekrar "yapısal değişimi" getirmeyi hedeflemekte ve ekonomik kalkınma sürecinde piyasaların ve devletin oynayabileceği rolün önemini vurgulamaktadır. Bu iktisatçılar kaynakların tahsisinde piyasaların ana mekanizma olması gerektiğini kabul etmekle birlikte; ürün çeşitlenmesi, yenilik ve keşifler ile ilk hareket eden firmaların yarattığı dışsallıkların tazmin edilmesi ve sanayileșme yolunda yatırımların koordinasyonu gibi konularda devletin hayati bir rol üstlenmesi gerektiğini ileri sürmektedir. $\mathrm{Bu}$ yaklașıma göre, her bölge belli bir faktör teçhizine (donanımına) ve yapısına sahiptir. Zaman içinde bu yapı değişir, bölgenin faktör teçhizi emek ve doğal kaynakların bol olduğu bir yapıdan; sermayenin, yeni teknolojilerin ağırlıkta olduğu ve altyapının iktisadi faaliyetleri desteklediği bir faktör teçhizi yapısına doğru değiştikçe bölgenin refah düzeyi yükselir. Bölgenin faktör donanımı yapısını iyileștirmenin yolu bölgenin cari (verili) faktör donanımına uygun düşen (iktisadi faaliyetleri) sektörleri desteklemektir. Başka bir ifade ile en yeni teknolojilerin ve altyapının değil mevcut faktör donanımına en uygun teknoloji ve altyapı ile karşılaştırmalı üstünlük yaratılması önerilmektedir. $\mathrm{Bu}$ bağlamda faktör donanımının belirlediği piyasa fiyatlarına dayanılması önerilirken; yeni teknoloji ve sektörlerin geliștirilmesi konusunda ise gelişmekte olan ülkelerin geride kalmanın avantajlarını kullanabilecekleri, gelişmiş ülkelerde olgunlaşan teknolojileri alıp kendilerine uyarlayabilecekleri görüşü öne çlkmaktadır. $\mathrm{Bu}$ bağlamda da devletin temel işlevi, bu teknolojileri alıp uyarlayacak veya taklit edecek öncü firma ve girişimcilerin keşif maliyeti ile ortaya çıkan dışsallıklarının içselleştirilmesi konusunda tedbirler almasıdır (Lin, 2012). Yeni Yapısalcı İktisadın bu görüşlerinin ampirik alana yansıması ve yeni araştırma araçları (ölçütleri) geliştirilmesi bir anlamda "Ürün Uzayı" adı verilen yaklaşımda vücut bulmuştur. Ürün Uzayı yaklaşımı herhangi bir teoriye dayanmadan büyümenin kaynaklarını açıklayabilecek/ölçebilecek değişkenler oluşturarak literatüre önemli kavramlar kazandırmıştır. Ürün Uzayının büyüme teorilerine katkısı teknolojiyi kaydıran faktör olarak, bilgi/beceri setinin dolaylı bir ölçütü olarak kullanılan ihracat sofistikasyonu (EXPY) ve ekonomik kompleksite endeksi (ECI) gibi kullanışlı ölçütler kazandırmasıdır. Ancak, bu ampirik çalışmalar bölgelerin gelişmesine ilişkin önemli ipuçları sunsa da henüz bölgelerin nasıl ve neden belli teknoloji, kurumsal yapı ve üretim teknolojilerini seçeceğine ilişkin net bilgiler sunmamaktadır. $\mathrm{Bu}$ çalışmada literatürden farklı olarak Evrimci Ekonomik Coğrafya, Yeni Yapısalcı İktisat ve Ürün Uzayı yaklaşımlarının farklı bakış açılarını birleştirmeye çalışan bir çerçevede Türkiye'nin üretim yapısının içerdiği üretken bilgi/beceri setinin ve bilgi yayılım mekanizmasının işleyişinin Türkiye'nin iktisadi büyüme sürecine etkisi araştırılmaya çalıșılmıştır. Böylece, ihracat sofistikasyonundaki artış iktisadi büyümeyi destekler olgusundan yola çıkarak Türkiye İstatistiki Bölge Birimleri Sınıflandırması (İBSS) Düzey 2 bölgelerinde bu argümanın geçerliliğinin test edilmesi amaçlanmıştır. Bu amaçla, ürün uzayı yaklaşımı göstergelerinden ECI (ekonomik karmaşıklık endeksi) ve EXPY (ihracat sofistikasyonu) değerleri kullanılmıştır.

Çalışma planı şu şekildedir. Giriş bölümünün ardından Teorik çerçeve yer almaktadır. Daha 
sonra literatürde, Türkiye için Ürün Uzayı yaklaşımını kullanan çalışmalara yer verilmiştir. Çalışmada yararlanılan veri setinin tanıtılmasının ardından, tahmin edilen modellerin elde edilmesine yönelik işlemler tartışılmış ve daha sonra bulgular kısmına yer verilmiştir. Çalışma, değerlendirme ile sonlandırılmıştır.

\section{TEORİK ÇERÇEVE}

$\begin{array}{lrr}\text { Evrimci } & \text { Ekonomik } & \text { Coğrafya yaklaşımı, } \\ \text { mekânın } & \text { ürün } & \text { kompozisyonunun }\end{array}$ dönüşümünde, dişsallıkların ve bilgi yayılım mekanizmalarının rolünü araștırmaktadır. Yeni Yapısalcı İktisat yaklaşımı ise gelişmiş ve gelișmekte olan ülkelerin gelir seviyeleri arasındaki ıraksama eğilimine rağmen, bazı ülkelerin gelir seviyesinin gelişmiş ülkelerin gelir seviyesine yakınsamasını, "yapısal değișim" bağlamında ele alarak, gelişmekte olan ülkelere bir takım politika önerileri getirmektedir. Ayrıca, verili bir zamanda, her bir mekânın sahip olduğu üretken bilgi/beceri seti ve faktör teçhizi farklı olduğundan, her bir mekânın üretim örüntüsünün de (yapısının/kompozisyonunun) farklı (kendine has) olmasının doğal olduğu kabul edilmektedir. $\mathrm{Bu}$ iki yaklaşımda da mekânın üretim yapısının patika bağımlı olduğu ve bugün yapılan tercihlerin gelecekteki üretim yapısını belirlerken, bugünün üretim yapısının da geçmişte yapılan tercihlerin bir sonucu olduğu kabul edilir. $\mathrm{Bu}$ bağlamda Evrimci Ekonomik Coğrafya yaklaşımı tercihlerin hangi patikanın seçilmesi gerektiği konusunda ideal olanın, mekânın üretim yapısının Jacobs dıșsallıkların en yüksek olmasını sağlayacak sektörlerden oluşması gerektiğini savunmaktadır (Boschma \&Frenken, 2003, 2006, 2009, 2010; Frenken, Oort, Verburg, \& Boschma, 2004:7; Frenken, \& Boschma, 2007). Yeni Yapısalcı İktisat ise tercihlerin, mekânın faktör teçhizine denk düşen "optimal üretim örüntüsüne” en hızlı şekilde ulaşmayı sağlayan

\footnotetext{
1Jacobs dişsallıklarda firma, endüstri çeşitliliği sebebiyle oluşan bilgi yayılımından yarar sağlar. Jacobs dışsallığın olduğu ekonomilerde firmaya ve sektöre dışsal ama bölgeye içsel oluşan dișsallıklar söz konusudur.
}

sektörlerden yana olması gerektiğini savunmaktadır (Lin, 2011; 2012). Ancak, optimal üretim örüntüsüne taşıyacak olan bu sektörler çoğu zaman piyasada doğru fiyat sinyallerinin oluşmaması, yanlış devlet politikaları ve teșvikler gibi nedenlerle gizil/örtük durumdadır. Ürün Uzayı yaklaşımında karşılaştırmalı üstünlüklere sahip şekilde üretim yapma potansiyeline sahip gizil/örtük olan bu sektörler tespit edilmeye çalışılır. Ürün Uzayı yaklaşımına göre yapısal dönüşüm hızının belirleyicisi mekânların sahip olduğu üretken bilgi/beceri setidir. Dolayısıyla, amaç üretken bilgi/beceri setini ve faktör teçhizini dikkate alan birtakım değişkenler aracılığıyla mekânların üretim yapısının optimal üretim yapısına doğru dönüşümünü sağlayacak politika önerilerinde bulunmaktır. Kısaca, Ürün Uzayı yaklaşımı mekânın optimal üretim kompozisyonunun ne olduğundan çok, bu optimale yaklaşmak için izlenecek yol haritasına odaklanmaktadır. Bir mekânda açıklanmış karşılaştırmalı üstünlüğe sahip şekilde üretim yapılan sektörler o mekânın uzmanlaşma yapısını oluşturmaktadır. $\mathrm{Bu}$ sektörlerin toplam sayısı ise o mekânın üretim yapısının zenginliği/niteliği yani çeşitliliği ile ilişkilidir. Çeşitlilik artışı ile Jacobs dışsallıkların rolü artarken, işgücüne olan talep de artış gösterir ${ }^{1}$. Böylece mekândaki ekonomi istihdam yaratarak büyümüş olur. Bu durum bilgi/beceri setinde artışla sonuçlanır. Bu yeni bilgi/beceri seviyesi daha üst seviyede olduğu için mekânın çeşitlilik ve uzmanlaşma örüntüsünü besler. Uzmanlaşma ile MAR (Marshal-Arow-Romer) dişsallıkların etkisi artar. Bu durum sektör içi daha yüksek verimlilik seviyesinde üretim yapılmasına neden olur². Daha yüksek verimlilik seviyesinde işgücüne olan talep azalsa da üretken bilgi/beceri setindeki genişleme büyümeyi arttırır. Böylece Şekil-1'de görüldüğü üzere verimlilik artışlarıyla işgücüne olan talep azalmakta ancak çeşitlenme sayesinde

2Marshall-Arrow-Romer (MAR) dişsallıkları; aynı endüstri içerisinde yerel firmaların karşılıklı etkileşimleri sonucunda ortaya çıkan bilgi yayılım mekanizmalarıdır. 


\section{TUNCER - N. COSSUN}

işgücüne olan talep artarak büyüme sağlanabilmektedir. Bu döngü ile ekonomi dengeli bir şekilde büyürken, bilgi/beceri setinde artış yaşanır. Artan üretken bilgi/beceri seti bu döngüyü sürekli hale getirir, yapısal dönüşüm hızlanır. Ancak, çeşitlilik verimliliği düşük alanlarda gerçekleşecek olursa bu erdemli döngü yakalanamayacaktır. Çeşitlilik ve uzmanlaşma birbirinden bağımsız kavramlar değildir. Bir alanda uzmanlaşmak için önce o alanda üretim yapmak gerekir. Çeşitlenme hangi alanda uzmanlaşılacağını belirlerken, uzmanlaşma yapısı da gelecekteki çeşitlilik yapısına zemin hazırlamaktadır. Böylece çeşitlilik ve uzmanlaşma arasında karşılıklı geri besleme ilişkisi bulunur. Benzer şekilde Jacobs dişsallıklar ve MAR dişsallıklar da karşılıklı nedensellik ve geri besleme ilişkisine sahiptir. Ancak nasıl ki doğada bir ekosistemdeki gelişim ve evrim süreci baskın türün müdahalesi, dış faktörler gibi çeşitli sebeplerle doğal dengeden uzaklaşabiliyorsa, üretimin gerçekleştiği iktisadi ekosistem de yanlış devlet politikaları, kapalı ekonomi, piyasa aksaklıkları gibi çok sayıda faktör nedeniyle bozulabilir. $\mathrm{Bu}$ durum mekânın üretim kompozisyonundaki çeşitlilik ve uzmanlașma yapısının bozulmasına yol açarak, üretim sürecindeki bilgi yayılım mekanizmalarını bozar ve üretken bilgi/beceri seti seviyesindeki artışı engeller. Böylece yapısal dönüșüm yavaşlar ve iktisadi büyüme olumsuz etkilenir. Böyle bir durumda yapısal dönüşümün bölgenin optimal üretim yapısına doğru gerçekleşmesinin yeniden sağlanması gerekmektedir. Ancak bu durumda da veri bir zamanda ve faktör teçhizatında bu optimalin nasıl tespit edileceği sorunu ortaya çıkmaktadır. Bu noktada Ürün Uzayı yaklaşımı bu konuda destek sağlayan veriye dayalı bir yöntem olarak öne çıkmaktadır. Ürün Uzayı yaklaşımı değişkenleri ile bölgelerin mevcut üretim yapısında teşvik edilmesi ve edilmemesi gereken sektörler tespit edilebilir ve mevcut üretim yapısında (cari dönemde) bulunmayan ancak karşılaștırmalı üstünlüğe sahip şekilde üretim yapılabilecek yeni alanlar tespit edilerek çeşitlenme sağlanabilir. Diğer yandan
Türkiye için yapılan çalışmalardan Coşkun, Tuncer \& Lopcu (2018) Türkiye'nin açılanmış karşılaștırmalı üstünlüğe sahip şekilde üretim yaptığı sektörlerin ortalama verimlilik (PRODY) değerinin örneklem ortalamasının altında olduğu sonucuna ulașmıșlardır. Kalkınma Bakanlığı tarafından hazırlanan 2014-2018 yıllarını kapsayan Onuncu Kalkınma Planı kapsamında "İmalat Sanayiinde Dönüşüm" adlı Özel İhtisas Komisyonu raporunda ise Türkiye'nin 2008 yılında çeşitlilik açısından dünya ortalamasının üstünde bir performans sergilediği görülürken, üretimin sıradanlığ ortalamasından farklılaşamadığı sonucu elde edilmiştir. $\mathrm{Bu}$ durum Türkiye'nin çeşitliliği yüksek bir ülke olmasına rağmen üretken bilgi/beceri setinin düşük olduğuna işaret etmektedir. Dolayısıyla Türkiye'nin bilgi beceri seti toplamı olarak MAR dışsallıkları temsilen ihracat sofistikasyonu (EXPY) değișkenindeki artış büyümeyi olumlu etkileyecektir. Ancak çeşitlilik yüksek olsa da bölgelerin sahip olduğu üretken bilgi/beceri seti seviyesi düşük olduğundan Jacobs dişsallıkların Türkiye'de iktisadi büyümeyle olan bağının zayıf olması muhtemeldir. Bu durum, Türkiye'nin yüksek çeşitlilik değerine karşılık gelen büyüme seviyesinde olamamasını bir ölçüde açıklamaktadır. Çünkü artan üretken bilgi/beceri setinin, verimliliği ve sofistikasyonu (PRODY ve PCI değeri) yüksek yeni ürünlerle ve yeniliklerle sonlanma ihtimali düşüktür.

Dolayısıyla, ECI değişkeni diğer bölgelere göre düşük olan bir bölgenin içerdiği üretken bilgi/beceri setinin karmaşıklığı düşüktür. $\mathrm{Bu}$ durumda bölgenin sektörler arası bilgi yayılım mekanizması olan Jacobs dişsallıkların zayıf olması beklenir. $\mathrm{Bu}$ sorun çeşitliliğin düşük olmasindan veya koordinasyon problemlerinden kaynaklanabileceği gibi temelde bölgenin mevcut üretim yapısının bölgenin optimal üretim yapısından uzaklaşmış olmasından kaynaklanmış olabilir. Bu durum, Jacobs ve MAR dişsallıklar arasında geri besleme ilişkisinde sorun olduğuna işaret etmektedir. Sonuç olarak, nitelikli yeni 
ürünlerde üretim yapmak için devletin yapısal dönüşümü hızlandıracak önlemler alması önem kazanmaktadır.

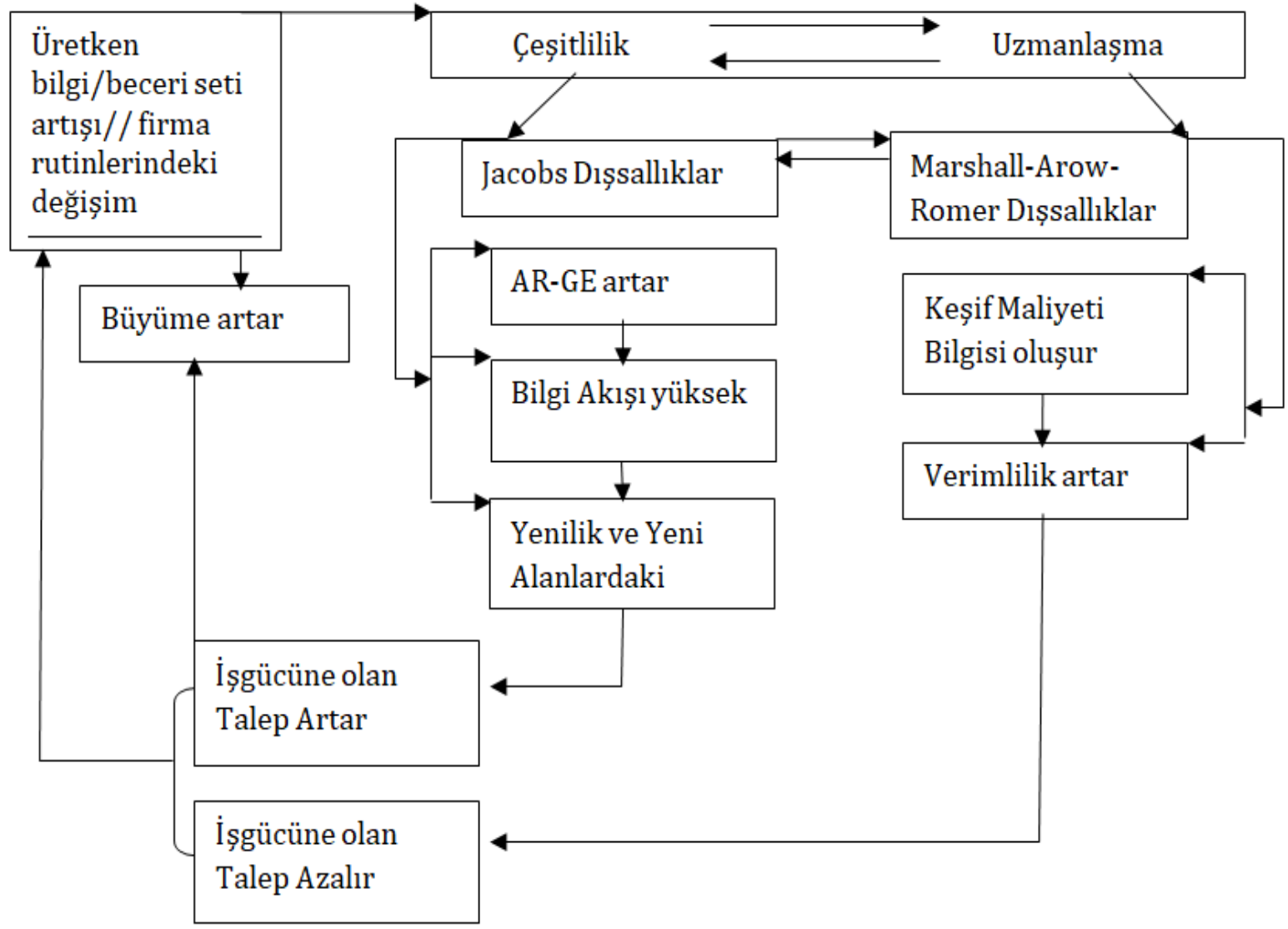

Şekil 1: Üretim Yapısı ve İktisadi Büyüme arasındaki İlişki, Coşkun (2019:37)

\section{TÜRKIYE İÇIN ÜRÜN UZAYI YAKLAŞIMINI KULLANAN ÇALIŞMALAR}

Türkiye'de Ürün Uzayı konusundaki ilk çalışmalar çoğunlukla kamu kurumlarının hazırladığı raporlar şeklindedir. Kamu kurumlarının raporları, doğal olarak belirli bir bölge için gelişme politikalarının tespitine odaklıdır. Ürün Uzayı ile ilgili ilk çalışma Dış Ticaret Müsteşarlığı için 2011 yılında TEPAV tarafından hazırlanmıștır. İllerimizin 2009 yılı için ihraç ettiği ürünlerin çeşitliliği ve sıradanlığı ölçülmeye çalışılmıştır. İhracatta en fazla çeşitliliğe sahip ve sıradanlığı en düşük ilin İstanbul buna karşıllı en az çeşitliğe sahip ilin Kars, sıradanlığı en yüksek olan ilin Gümüșhane olduğu sonucuna ulașılmıștır. Çalışmada 2009 yılı için illerin sektörel yapısının ortalama sıradanlığını ve nitelikli olarak yeni alanlara sıçrama kabiliyetini içeren strateji matrisindeki konumları göz önüne alınarak illerin ihtiyacına göre farklı hükümet politikaları önerilmiştir. Ürün Uzayı ile ilgili bir diğer çalışma ise Kalkınma Bakanlığı tarafından 2014-2018 yillarını kapsayan Onuncu Kalkınma Planı kapsamında hazırlanan "İmalat Sanayiinde Dönüşüm" adlı Özel İhtisas Komisyonu Raporudur. Bu raporda Türkiye ve diğer ülkelerin çeşitliliği ve üretimlerinin sıradanlığı hesaplanarak Türkiye'nin performansı dünya ortalaması ile kıyaslanmıştır. Rapor bulguları Türkiye'nin 1980 yılında sıradanlık ve çeşitlilik açısından dünya ortalamasına yakın olduğunu 2008 yılına gelindiğinde çeşitlilik açısından dünya ortalamasının üstünde bir performans sergilediğini ancak üretimin sıradanlığ açısından dünya ortalamasından farklılaşamadığına işaret etmiştir. Aynı raporda dünyanın en büyük 20 ekonomisi için EXPY değişkeni hesaplandığında Türkiye'nin 


\section{TUNCER - N. COŞKUN}

ihracatının karmaşıklık düzeyinin oldukça düşük olduğu görülmüştür (Kalkınma Bakanlığı, 2014:12). Zafer Kalkınma Ajansı ve TEPAV ortak bir çalışma ile Afyonkarahisar, Kütahya, Manisa ve Uşak illerini kapsayan TR33 Bölgesi'ndeki üretim yapısını inceleme yoluna gitmiştir. Önceki raporlarda olduğu gibi bölge için çeşitlilik ve sıradanlık değerleri hesaplamış ve strateji matrisi oluşturulmuştur. İstihdam ve ihracat verileri kullanılarak yapılan analizlerde bu bölgede (TR33) en yüksek üretim çeşitliliğine sahip ilin Manisa olduğu görülmüștür. Ayrıca, Türkiye'deki illerin ortalama sıradanlığı ve çeşitliliği 2011 yılı için hesaplanmış ve ihracatta en fazla çeşitliliğe sahip ilin İstanbul buna karşılık en az çeşitliğe sahip ilimizin Gümüşhane olduğu görülmüştür. 2011 yılı için illerin sektörel yapısının ortalama sıradanlığını ve nitelikli yeni alanlara sıçrama kabiliyetini gösteren strateji matrisindeki konumlarına göre illerin ihtiyacı olan devlet politikaları tartışılmıştır. Ardından, TR33 bölgesinde yer alan ilçelerin strateji matrisindeki konumlarına göre izlemeleri gereken politikalar belirlenmeye çalışılmıştır. Coşkun \& Tuncer (2016) ihracat sofistikasyonunun kamu alt yapı yatırımları ve beșerî sermaye ile ilişkisini Türkiye için araştırmıştır. Çalışmada, bir bölgenin bilgi/ beceri setindeki artışın, sınır komşuluklarında da bilgi/beceri seti artışına neden olduğu sonucuna ulaşılmıştır. Ayrıca mekânsal etkileşimin karşılıklı olmasından dolayı, belirli bir bölgedeki bilgi/beceri setindeki artışın komşusundaki bir firmanın/girişimcinin ürettiği yeni bir bilgiden kaynaklanmış olabileceği vurgulanmıștır. Türkiye'de İBBS Düzey 2 bölgelerinde bilgi/beceri seti seviyesinin, beşerî sermaye seviyesi ve kamu alt yapı yatırımlarıyla pozitif yönlü bir ilișkiye sahip olduğu yönünde bulgular elde edilmiştir. Buna göre, Türkiye İBBS Düzey 2 bölgelerinde 2011 yılı verileri bağlamında beşerî sermaye ve kamu alt yapı yatırımlarının ihracat sofistikasyonunu belirleyen önemli faktörler olduğu sonucuna ulaşılmıştır. Arıcıoğlu, Coşkun \& Tuncer (2017), 2014 yllı ihracat ve istihdam verilerini kullanarak Türkiye İBBS Düzey 2 bölgelerinin üretim yapısının sıradanlığı ve çeşitliliğini analiz etme yoluna gitmiştir. İhracat ve istihdam verilerinde farklı sinıflandırma sistemiyle hazırlanmasından dolayı sonuçları karşılaştırabilmek amacıyla imalat sanayi sektörleri 22 farklı sektörde gruplandırılmıştır. Bölgesel çalışmalarda ihracat yerine SGK verilerinin kullanımının daha tutarlı sonuçlar verdiği görülmüștür. Çalışma, Hidalgo \& Hausmann (2009) tarafindan kullanılan yansıma yöntemi ile mevcut üretim yapısına göre bölgeler gruplandırılmıştır. Ayrıca PRODY ve EXPY değişkenlerinin logaritmik farkları ve yoğunluk endeksi kullanılarak Türkiye için yüksek katma değer yaratan sektörler belirlenmeye çalışılmıştır. Son olarak çalışmada strateji matrisine göre, bölgelerin yeni ürünlere siçrama potansiyeli ve ortalama sıradanlık seviyesine göre izlenmesi gereken politikalar tespit edilmeye çalışılmıştır. Bulgular, TR10 (İstanbul) bölgesinin Türkiye'nin diğer bölgelerinden slyrılarak, sıradanlığı düşük, niteliği yüksek ürünlerde üretim yaptığı, benzer şekilde bölgenin TR10 (İstanbul) diğer sektörlerde de rekabetçi üretim yapacak şekilde sıçrama yapma potansiyeli en yüksek bölge olduğuna işaret etmektedir. TR42 (Kocaeli, Sakarya, Düzce, Bolu, Yalova), TR31 (İzmir), TR51 (Ankara), TR 21 (Tekirdağ, Edirne, Kırklareli), TR61 (Antalya, Isparta, Burdur) ve TR62 (Adana, Mersin) bölgeleri strateji matrisinde TR10 bölgesiyle aynı grupta yer almıştır. $\mathrm{Bu}$ bölgelerin mevcut üretim yapısında bulunan ve nitelik artışı yaratacak sektörler için uygun yatırım ortamı sağlanmasına yönelik politikalara ihtiyaç olduğu vurgulanmıştır. TR90 (Trabzon, Ordu, Giresun, Rize, Artvin, Gümüşhane), TRB1 (Malatya, Elâzığ, Bingöl, Tunceli), TR81 (Zonguldak, Karabük, Bartın) ve TR63 (Hatay, K. Maraş, Osmaniye) bölgeleri de strateji matrisine göre nitelikli ürünler üretebilecek beceri setinden yoksun olduğu için yeni sektörlere sıçrama kabiliyeti de düşük bulunmuştur. Çalışmada bu bölgelerde rekabet gücünün arttırılması amacıyla piyasanın çeşitlendirilmesine yönelik politikalara ihtiyaç olduğu ve yabancı yatırımları çekecek 
politikaların bölge için önemli olabileceği sonucuna ulaşılmıştır. Ayrıca bu bölgelerde alt yapıya ve kaliteye yapılacak yatırımlara ihtiyaç olduğu vurgulanmıştır. Pyka, Kuştepeli, \& Hartman (2016), 2013 yılı için Türkiye'nin ekonomik karmaşıklık endeksine göre dünyada 40. sırada yer aldığı ve Avrupa ülkelerini yakalamak için avantaja sahip olduğu belirtilmiştir. Türkiye'nin ancak inovasyona, öğrenmeye dayalı bilgi-temelli ekonomiye dönüșerek iktisadi büyümesini arttırabileceği vurgulanmiștır. Tuncer, Lopcu, Coşkun, \& Arıcıoğlu (2017) 2014 yılı istihdam verileriyle yaptıkları çalışmada birbirlerine yakın bölgeleri gruplandırarak bölgelerde mevcut olan üretim ve ihracat yapısına göre politika önerilerinde bulunma yoluna gitmiştir. İlk olarak bölgelerin strateji matrisindeki konumları belirlenmiştir. Daha sonra Hiyerarşik Yöntem, K Ortalamalar yöntemi ve İki Așamalı kümeleme olmak üzere üç farklı kümeleme yöntemi kullanılarak, bölgelerin dört farklı kümeden hangi kümeye ait olabileceği kesinleștirilmeye çalışılmıştır. Son olarak, bölgelerin yer aldıkları kümelerle ECI endeksleri karşılaştırılmıştır. Bulgular, sirasiyla TR 21, TRC1, TR10, TR42 ve TR72 bölgelerinin Türkiye'nin en yüksek ECI değerine sahip olduklarını, TRC1 ve TR72 bölgelerinin ürün çeşitliliğinin düşük olmasına rağmen nadir (sıradan olmayan) ürünler ürettiği için ECI değerlerinin yüksek çıktığına işaret etmiş ve strateji matrisini destekler şekilde bu bölgelerde ürün çeşitlenmesini sağlayacak politikaların önemli olduğunu göstermiştir. TRA2, TRB2, TR90, TRA1, TRC3 ve TR61 ise hem ürün çeşitliliğinin düşük olması hem de üretilen ürünlerin sıradan ürünler olması sebebiyle düşük ECI değerlerine sahip bulunmuştur. Bazl bölgelerin ait oldukları kümelerde farklılıklar göze çarpmıştır. Bunun başlıca sebebinin yöntem olduğu düşünülse de bu bölgelerin ihtiyaçları olan politikalar konusunda daha dikkatli davranılması gerektiği vurgulanmıştır.

1Türkiye İBBS Düzey 2 Bölge kodlarının açıklamaları Coşkun (2019) Ek-11'de yer almaktadır. SGK verileri
Örneğin, A kümesinde yer alan TR10, TR21, TR31, TR42, TR51 bölgeleri dört yönteme göre de aynı grupta yer alırken, TR62 bölgesinin iki aşamalı kümeleme yönteminde $B$ kümesinde yer aldığı görülmüştür. Dolayısıyla bu bölgenin, finansmana erişim şartlarının iyileştirilmesi ve yaşam kalitesinin arttırılmasına yönelik politikaların yanı sıra bağlanabilirliğin arttırılması, kalkınma odaklı devlet altyapı yatırımları gibi politikalara da ihtiyaç duyabileceğinin göz önünde bulundurulması gerektiği ileri sürülmüştür. Coşkun, Tuncer\& Lopcu (2018) 2015 yılı 214 sektör ile Çin ve 35 OECD ülkesinin çeşitlilik, sıradanlık, açık orman (OF), ortalama PRODY gibi değerlerini hesaplayarak, bu ülkeler arasında Türkiye'nin yerini araştırmışlardır. Türkiye'nin ortalama PRODY değeri olarak örneklemin en alt sırasında yer aldığı sonucuna ulaşılmıştır. $\mathrm{Bu}$ durum Türkiye'nin düşük kişi başına düșen reel GSYİH ve düşük EXPY değerinin nedeni olarak görülmüştür. Bununla birlikte Türkiye'nin bazı nadir ürünlerde uzmanlaştığı, çeşitliliğinin yüksek olduğu ve yüksek OF değeriyle sıradan olmayan ürünlere sıçrama potansiyelinin yüksek olduğu dolayısıyla, Türkiye'nin yüksek PRODY değerine sahip ürünlere sıçrayabilecek potansiyele sahip olduğu ve bu ürünlere yönelmesini sağlayacak politikalarla yüksek büyüme oranları elde edilebileceği sonucuna ulaşılmıştır. Yıldırım (2018) ise Türkiye'nin çok sayıda sofistike ürüne yakın ürünlerde üretim yaptığını ancak sofistike ürünlerde karşılaştırmalı üstünlük kuracak şekilde üretmeye başlamadığını iddia etmiştir. 2000 ve 2012 yılları için HS4 verileriyle makine, elektrikli makine ve kimya sektörlerinde Türkiye'nin kolay sıçrama gerçekleştirebileceği öncü sektörler olduğu sonucuna ulaşmıştır.

\section{VERİ SETİ VE YÖNTEM}

Türkiye'nin İstatistiksel Bölge Birimleri Sınıflaması (İBBS) Düzey 2 Bölgeleri için Sosyal Güvenlik Kurumundan (SGK) elde edilen 20042014 yıllarını kapsayan istihdam verileri kullanılmıştır ${ }^{1}$. Veriler NACE Rev. 2 (4-dijit)

NACE Rev. 2 (2017) sinıflandırmasına göredir. Veriler SGK ile protokol kapsamında elde edilmiş olup, 2016'ya 


\section{TUNCER - N. COSSUN}

sinıflandırılmasına göre olup 2004 yılı 253, 2005-2013 yılları arasinda 254 ve 2014 yılı 232 imalat sanayi sektörüyle çalışılmıştır. Kullanılan kişi başına düșen (bölgesel) gayrisafi yurt içi hâsıla (KBGSYİH) verileri 2004-2014 yılları arasında Türkiye İstatistik Kurumu (TÜIK) Ulusal Hesaplar veri tabanından alınmıştır. GSYİH veri tabanından 2009 yılı fiyatlarına göre elde edilen deflatör yardımıyla bölgesel KBGSYIH fiyat hareketlerinden arındırılarak reel hale getirilmiştir. Beşerî sermaye düzeyi TÜİK Eğitim İstatistikleri veri tabanından elde edilen lise ve altı mezun kişi sayısı, lise ve dengi meslek okulu mezunu sayısı ve yükseköğretim mezunu sayılarından hareketle hesaplanmıştır. Hausman vd. (2011) ve Hausmann, Hwang, \& Rodrik, (2007) tarafından önerilen ECI ve EXPY değerlerinin hesaplanması amacıyla, ilk olarak ürün sofistikasyon PRODY değeri hesaplanmıştır. PRODY bir alt bölgenin belirli bir sektördeki istihdam payının, tüm alt bölgelerin aynı sektördeki istihdam payı toplamina oranlanarak ve bölgenin kişi başına milli geliriyle ağırlıklandırılarak elde edilir. Böylece her sektör için bir ortalama çıtı seviyesi (verimlilik düzeyi) elde edilir. Bu değişken, verili bir ürün veya ihracat sepetine karşıllı gelen fert başına ağırlıklı ortalama gelir seviyesini gösterir. Ağırlık olarak bir çeşit açıklanmış karşılaştırmalı üstünlükler ölçütü kullanılır. PRODY değeri, yaratılan katma değerin sektörlerin yoğunluğuna göre dağıtılmasıyla elde edildiğinden, sektörlerin verimliliği hakkında önemli bilgiler ihtiva eder.

$\operatorname{PRODY}_{p}=\sum_{c} \frac{X_{c p} / X_{c}}{\sum_{c}\left(X_{c p} / X_{c}\right)} Y_{c}$

Burada, $X_{c p} c$ alt bölgesinin $p$ sektöründe çalışan kişi sayısı, $X_{c} c$ alt bölgesinin toplam çalışan sayısı ve $Y_{c} c$ alt bölgesinin kişi başına milli geliri ya da kişi başına katma değeridir.

kadar güncelleme yapılmış olmasına rağmen verilere erişim tarihi olan 2017 yılında bölgesel büyüme rakamları için ilan edilen veriler 2014 yılında sonlandığından, analizler 2004-2014 dönemini kapsamaktadır.
Bir diğer önemli değişken olan ihracat veya ürün sofistikasyonu (EXPY) ise bölgedeki üretimin referans bölge içindeki payının PRODY ile ağrılıklandırılmasıyla elde edilen bir değișkendir. EXPY değeri verili bir ürün veya ihracat sepetine karşılık gelen verimlilik seviyesini yansitır. Bölge istihdamının sektördeki payının bölgede üretilen ürünlerin verimliliğiyle ağırlıklandırılması olarak düşünülebilir. Genelde ihracatla ölçüldüğünden ihracat sofistikasyonu olarak adlandırılır. EXPY teknolojik olmayan dişsallık türü olarak keșif maliyeti ve kar arasındaki ilişkinin kurgusuna dayandırılabilir. Şöyle ki, "yerel keşif maliyeti bilgisi” kar güdüsü aracılığıyla girişimci sayısını etkileyerek verimlilik artışına yol açar. $\mathrm{Bu}$ verimlilik artışları da üretimde kullanılan üretken bilgi/beceri seti aracılığıyla iktisadi büyümeyi sağlar. Yüksek EXPY değeri, o bölgede büyümenin de yüksek olacağı anlamına gelirken; EXPY değeri düşük olan bir bölgenin içerdiği üretken bilgi/beceri setinin de düşük olması beklenir. Bölgenin "sofistikasyonu" keşif maliyeti bilgisini de içeren, üretim sürecinde kullanılan tüm bilgi/beceri setinin toplamını ifade etmektedir. Dolayısıyla, yerelleşme ekonomilerinde endüstri içi oluşan bilgi beceri setinin ekonomideki toplamını ifade etmesi açısından önemlidir. 0 halde, düşük EXPY değeri bölgenin uzmanlaşma yapısındaki bilgi yayılım mekanizması olan MAR dışsallıklarda sorun olduğunun göstergesi kabul edilir.

$E X P Y_{c}=\sum_{p} \frac{X_{c p}}{X_{c}} \operatorname{PRODY}_{p}$

Yerelleşme/Yoğunlaşma endeksi (LQ) bir bölgenin üretim yapısının yoğunlaştığı alanların tespitinde kullanılmaktadır. LQ, referans bölgenin belirli bir sektördeki istihdam payının, örneklemin tamamında aynı sektördeki istihdam payına oranlanmasıyla bulunur ${ }^{1}$. Ekonomik Komplekslik Endeksi

\footnotetext{
${ }^{1}$ Burada çalışmada ana örneklem, Türkiye olup, Düzey 2 bölgelerinin her biri referans bölgedir.
} 
(ECI) bölgedeki üretimin ne kadar çeşitli ve sıradan olmayan (nadir) ürünlerden oluştuğunun bir ölçüsüdür. Yansıma metodunun bir sonucu olarak elde edilen $\tilde{M}_{c c^{\prime}}$ matrisin en yüksek ikinci öz değerine karşıllk gelen öz vektörden kendi ortalamasının çıkartılıp standart sapmasına bölünmesiyle elde edilmektedir.

$$
\begin{gathered}
\tilde{M}_{c c^{\prime}}=\sum_{p} \frac{M_{c p} M_{c^{\prime} p}}{k_{c, 0} k_{p, 0}} \\
E C I=\frac{\vec{K}-<\hat{K}>}{\operatorname{stdev}(\vec{K})}
\end{gathered}
$$

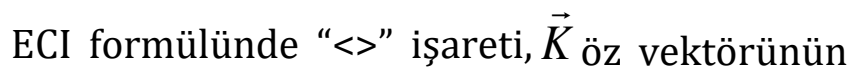
ortalaması ve "stdev" standart sapması olmak üzere $\vec{K}, \tilde{M}_{c c^{\prime}}$ matrisinin en yüksek ikinci öz değerine karşılık gelen öz vektördür. Ekonomik karmaşıklık endeksi bölgelerin çeşitlilik ve ortalama sıradanlığından yola çıkarak elde edildiğinden bölgede yaratılan Jacobs dıșsallıkların bir ölçüsü olarak düşünülebilir. Bir bölgede ECI endeksi ne kadar yüksekse o bölgede sektörel çeşitliliğin yarattığı bilginin sektörler arası yayılımının da o ölçüde yüksek olması beklenebilir.

Beşerî sermaye seviyesi, mezuniyet durumlarına göre kişi sayılarının aktif nüfus ile yaklaşık eğitim yılı kullanılarak ağırlıklandırılmasıyla elde edilen endeks değerleridir ${ }^{1}$. Bölgesel kamu alt yapı yatırımları Kalkınma Bakanlığı'nın Kamu yatırımlarının illere göre dağılım istatistiklerinden elde edilmiştir. Yıl ortası nüfus bölgesel GSYİH ve bölgesel KBGSYİH değerlerinin oranından elde edilmiştir. Elde edilen yıl ortası nüfus ile kişi başına düşen kamu alt yapı yatırımları hesaplanmıștır. Analizlerde kiși bașına düșen kamu alt yapı yatırımlarının KBGSYİH içindeki payı kullanılmıştır.

\footnotetext{
${ }^{1}$ Mankiw, Romer, \& Weil (1992) takiben 15 yaş üzeri nüfusun lise ve altı mezun kişi sayısı, lise ve dengi meslek okulu mezunu sayısı ve yükseköğretim mezunu sayısı toplam nüfusa oranlanarak hesaplanmıștır. Daha sonra okuma yazma bilmeyen 0.1 , lise ve altı 3.25 , lise
}

Tablo 1: Betimleyici İstatistikler (2005-2014)

\begin{tabular}{|l|l|l|l|l|}
\hline Değişken & Ort. & St. Sap. & En K. Göz. & En B. Göz. \\
\hline Büyüme (g) & 0,04 & 0,04 & $-0,11$ & 0,17 \\
\hline KBGSYIHH$_{\mathrm{t}-1}$ & 9,33 & 0,40 & 8,41 & 10,3 \\
\hline EXPYt-1 & 9,40 & 0,13 & 9,00 & 9,70 \\
\hline ECI $_{\mathrm{t}-1}$ & 0,00 & 0,98 & $-1,40$ & 2,87 \\
\hline Beşerî Sermaye (h) & 4,05 & 0,42 & 2,98 & 5,29 \\
\hline KamuYatırımları (k) & 1,50 & 0,90 & 0,27 & 5,43 \\
\hline
\end{tabular}

Yukarıdaki tabloda kullanılan değișkenlerin betimleyici istatistiklerine yer verilmiştir. Buna göre 2005-2014 yılları arasındaki bölgesel büyüme rakamlarının ortalaması yaklaşık olarak 0,04 ve standart sapması da yaklaşık olarak 0,05'dir. Bölgesel büyüme rakamlarında gözlenen en küçük değer -0,11 iken, en büyük değer 0,17'dir. Başlangıç KBGSYIH değerlerinin ortalaması 9,34, standart sapması ise yaklaşık 0,41 civarındadır. Bu değișkenin gözlenen en küçük değeri 8,41 iken, en büyük gözlem değeri 10,30'dur. EXPY değerlerinin ortalaması 9,41, standart sapması ise yaklaşık 0,13'dür. EXPY değerlerinin gözlenen en küçük değeri 9,01 iken, en büyük gözlem değeri 9,70'dur. Beşerî sermaye seviyesinin ortalaması 4,05 iken, standart sapması 0,42'dir. Gözlenen ek küçük değer 2,98 iken en büyük değer ise 5,29 olmuştur. Kamu yatırımlarının ortalaması 1,51, standart sapması 0,90 civarındadır. Gözlenen en küçük değer 0,28 , en büyük değer ise 5,43 olmuştur. Kamu yatırımları ise en yüksek standart hataya sahip değişken olarak dikkat çekmektedir. Ekonomik kompleksite endeksinin ortalaması yaklaşık olarak sıfır civarında iken, standart sapması 0,98 civarındadır. Gözlenen en küçük değer -1,40, en büyük değer ise 2,87 civarındadır.

\section{5. ÇALIŞMANIN TEMEL MODELLERİ}

Solow (1957) modelinde, sermaye ve emek girdilerinin kullanıldığı ve üretimde ölçeğe göre sabit getirinin olduğu bir ekonomi tasavvur etmiștir. Faktör verimliliği (teknoloji) Solow artığı içerisinde dışsal olarak modele dâhil edilmiştir. Böylece büyümeyi, tasarruflar

ve dengi meslek okulu 5.5, yükseköğretim 7.5 ile ağırlıklandırılarak beşerî sermaye seviyesi hesaplanmıștır. Ağırlıklandırmada eğitim yılı oranları baz alınmıştır. Detaylı bilgi için Barro \& Lee (2013)'e bakınız. 
ve faktör birikimi ile ilişkilendirir. Fakat SolowSwan modelini temel alan uygulamalı çalışmalardaki en önemli sonuç, büyümenin çok az bir kısmının faktör birikimi ile açıklanması ve büyümenin kaynağının faktör birikiminden çok Solow artığına dayanması olmuştur. Böylece modele teknolojinin içsel olarak dâhil edilmesi gerekliliği doğmuştur.

Üretim faktörü olarak fiziki sermayenin ve beşerî sermayenin olduğu ve teknolojinin içsel olarak modele dâhil edildiği üretimde ölçeğe göre sabit getiri varsayımı altında Cobb Douglas üretim fonksiyonu denklem (5)'deki gibi olsun.

$$
Y=K^{\alpha}{ }_{t} H^{\beta}{ }_{t}\left(A_{t} L_{t}\right)^{1-\alpha-\beta}
$$

Bu modelde $y=Y_{t} / L_{t}, k=K_{t} / L_{t}, h=H_{t} / L_{t}$ ve $\tilde{y}=Y_{t} / A_{t} L_{t}, \tilde{k}=K_{t} / A_{t} L_{t}, \tilde{h}=H_{t} / A_{t} L_{t}$ olmak üzere denklem (5), denklem (6)'de olduğu gibi yazılabilir.

$\tilde{y}=\tilde{k}^{\alpha} \tilde{h}^{\beta}$

$s_{K} Y_{t}$ ve $s_{H} Y_{t}$ sirasiyla gelirin tasarruf edilerek fiziksel ve beşeri (eğitim) yatırımına ayrılan miktarı olmak üzere, kamu kesiminin ve dış ticaretin olmadığı durumda fiziki ve beșeri sermaye için $\frac{d \ln \tilde{k}}{d t}=\frac{\tilde{k}}{K_{t}}$ ve $\frac{d \ln \tilde{h}}{d t}=\frac{\tilde{h}}{H_{t}}$ olmak üzere, durağan durumda, $\tilde{k}$ ve $\tilde{h}$ sabit oranda büyüyeceğinden, logaritmalarının zamana göre türevleri sıfır olur. Bu durumda durağan durumda $\stackrel{0}{\tilde{k}}$ ve $\stackrel{0}{\tilde{h}}$ sifır olmak üzere aşağıdaki denklemler yazılabilir:

$$
\begin{aligned}
& \tilde{\tilde{k}}=s_{K} \tilde{y}-\tilde{k}(g+n+\delta) \\
& \tilde{h}=s_{H} \tilde{y}-\tilde{h}(g+n+\delta)
\end{aligned}
$$

$\tilde{k}_{\text {ve }} \tilde{h}$ için durağan durum değerleri olan $\tilde{k}^{*}$ ve $\tilde{h}^{*}$ yazıldıktan sonra denklem (7) ve denklem (8) yeniden düzenlenirse, sirasıyla denklem (9) ve (10) elde edilir.

$$
\begin{aligned}
& \ln \tilde{k}^{*}=\frac{1-\beta}{1-\alpha-\beta} \ln s_{K}+\frac{\beta}{1-\alpha-\beta} \ln s_{H}-\frac{1}{1-\alpha-\beta} \ln (n+g+\delta) \\
& \ln \tilde{h}^{*}=\frac{\alpha}{1-\alpha-\beta} \ln s_{K}+\frac{1-\alpha}{1-\alpha-\beta} \ln s_{H}-\frac{1}{1-\alpha-\beta} \ln (n+g+\delta)
\end{aligned}
$$

Durağan durumda kişi başına etkin değerler cinsinden üretim fonksiyonu ve bu fonksiyonun logaritması sırasıyla denklem (11) ve (12)'deki gibidir.

$$
\begin{aligned}
& \tilde{y}^{*}=\left(\tilde{k}^{*}\right)^{\alpha}\left(\tilde{h}^{*}\right)^{\beta} \\
& \ln \tilde{y}^{*}=\alpha \ln \tilde{k}^{*}+\beta \ln \tilde{h}^{*}
\end{aligned}
$$

Denklem (9) ve denklem (10), denklem (6)'da $\ln \tilde{k}^{*}$ ve $\ln \tilde{h}^{*}$ yerine yazılırsa aşağıdaki denklem (13) elde edilir.

$$
\ln \tilde{y}^{*}=\frac{\alpha}{1-\alpha-\beta} \ln s_{K}+\frac{\beta}{1-\alpha-\beta} \ln s_{H}-\frac{\alpha+\beta}{1-\alpha-\beta} \ln (n+g+\delta)
$$

Diğer taraftan, denklem (6)' nın zamana göre türevi alındığında denklem (14)' ye ulaşılır.

$$
\frac{d \ln \tilde{y}}{d t}=\alpha \frac{d \ln \tilde{k}}{d t}+\beta \frac{d \ln \tilde{h}}{d t}
$$

Denklem (14)' de yer alan $\frac{d \ln \tilde{y}}{d t}$ ifadesinin birinci dereceden Taylor açlımı aşağıdaki gibidir.

$$
\frac{d \ln \tilde{y}}{d t}=-(1-\alpha-\beta)(n+g+\delta)\left(\ln \tilde{y} / \ln \tilde{y}^{*}\right)
$$

$(1-\alpha-\beta)(n+g+\delta)=\lambda$ olmak üzere denklem (16) aşağıdaki gibi yazılabilir.

$$
\frac{d \ln \tilde{y}}{d t}=-\lambda\left(\ln \tilde{y} / \ln \tilde{y}^{*}\right)
$$

Denklem (16), birinci dereceden lineer diferansiyel denklem olup bu denklemin çözümü aşağıdaki gibidir:

$$
\ln \tilde{y}=e^{-\lambda t} \ln \tilde{y}_{0}+\left(1-e^{-\lambda t}\right) \ln \tilde{y}^{*}
$$

Yukarıdaki denklemde ilk olarak eşitliğin her iki tarafından $\ln \tilde{y}_{0}$ ifadesi çıkartıldığında şu ifade elde edilir.

$\ln \left(\tilde{y} / \tilde{y}_{0}\right)=-\left(1-e^{-\lambda t}\right) \ln \tilde{y}_{0}+\left(1-e^{-\lambda t}\right) \ln \tilde{y}^{*}$ 
Denklem (18)'deki eşitlikte yer alan $\tilde{y}_{t}$ ifadesi $\tilde{y}=Y_{t} / A_{t} L_{t} \quad$ şeklinde tanımlanmıştı. $\mathrm{Bu}$ eşitlikte denklemin sol yanı $A_{t}$ ile çarpılır ve bölünürse, $\tilde{y}_{t}$ yerine $y_{t}$ ifadesini kullanmak gerekir. Böylece, $\ln \tilde{y}_{0}=\ln \left(y_{0} A_{0}\right)$ olur. Ayrıca denklem (13)'de yer alan $\ln \tilde{y}^{*}$ ifadesi yerine yazıldığında aşağıdaki denklem elde edilir.

$$
\begin{aligned}
\ln \left(y / y_{0}\right)= & -\left(1-e^{-\lambda t}\right) \ln y_{0}+\left(1-e^{-\lambda t}\right)\left[\frac{\alpha}{1-\alpha-\beta} \ln s_{K}+\frac{\beta}{1-\alpha-\beta} \ln s_{H}\right. \\
& \left.-\frac{\alpha+\beta}{1-\alpha-\beta} \ln (n+g+\delta)\right]+g+\left(1-e^{-\lambda t}\right) \ln A_{0}
\end{aligned}
$$

Burada, Mankiw, Romer, \& Weil (1992) başlangıç teknoloji değerini $\ln A_{0}=\ln (A)+\varepsilon_{t}$ şeklinde tanımlamıştır. Ayrıca, A'nın büyüme oranı $g$ ülkeler arası eşit kabul edilerek sabit terime eklenmiştir. Bu çalışmada teknoloji farklılıklarını açıklayan faktör olarak işgücü başına düşen beklenen çıktı miktarı CobbDouglas fonksiyonundan yola çlkarak elde edilmiştir ${ }^{1}$. Dolayısıyla, $Z_{t}$ kurumların iyiliği, bilgi/beceri seti gibi teknoloji farklılıklarını açıklayan faktörler olmak üzere $A\left(Z_{t}\right)=E\left(Y_{t}\right) / L_{t} \quad$ olarak tanımlandığında, $\ln \left(A\left(Z_{t}\right)\right)$ lineer bir fonksiyondur. Bu durumda $g\left(Z_{0}, Z_{t}\right)=\ln \left[A\left(Z_{t}\right) / A\left(Z_{0}\right)\right]$ olur. Eğer ki $g\left(Z_{0}, Z_{t}\right)=\bar{g}$ olduğu varsayılırsa denklem (20) elde edilmiş olur.

$$
\begin{aligned}
\ln \left(y / y_{0}\right)= & -\left(1-e^{-\lambda t}\right) \ln y_{0}+\left(1-e^{-\lambda t}\right)\left[\frac{\alpha}{1-\alpha-\beta} \ln s_{K}+\frac{\beta}{1-\alpha-\beta} \ln s_{H}\right. \\
& \left.-\frac{\alpha+\beta}{1-\alpha-\beta} \ln (n+g+\delta)\right]+\bar{g}+\left(1-e^{-\lambda t}\right) \ln A\left(Z_{0}\right)
\end{aligned}
$$

Mankiw, Romer, \& Weil (1992) modelinden yola çıkarak elde edilen denklemlerde Islam (1995)' in çalışmasını takiben panel veri seti için başlangıç değerleri tanımlanmıştır. Böylece, denklem (21) elde edilir.

\footnotetext{
${ }^{1}$ Bilgi beceri setinin elde edilişine yönelik işlemler ve MAR dışsallıklarla olan ilişkisi için detaylı bilgi için Coşkun (2019) Ek-5 ve Ek-6'dan yararlanılabilir.
}

$\ln \left(y_{t} / y_{t-1}\right)=-\left(1-e^{-\lambda t}\right) \ln y_{t-1}+\left(1-e^{-\lambda t}\right)\left(\ln \tilde{y}^{*}+\ln A\left(Z_{t-1}\right)\right)+\bar{g}$

Ürün Uzayı yaklaşımına göre, yerel keşif maliyeti bilgisinin yarattığı pozitif dışsallıklar kar güdüsü aracılığıyla girişimci sayısını etkileyerek verimlilik artışlarına sebep olmaktadır. Bu verimlilik artışları da üretimde kullanılan yerel bilgi/beceri setini geliştirerek iktisadi büyümeyi destekler. Bu çalışmada Ürün Uzayı yaklaşımının Neo-klasik tarafı incelenmektedir. $\mathrm{Bu}$ nedenle modele bilgi/beceri setinin dolaylı bir ölçümü olarak ihracat sofistikasyonu verimlilik artışlarını temsil eden (teknolojiyi kaydıran) faktör olarak dâhil edilmiștir. Zira Hausmann, Hwank, \& Rodrik (2007)'e göre beklenen maksimum verimlilik girișimci sayısı ve beşerî sermaye tarafından belirlenir. Alt yapı yatırımları ve devlet teşvikleri girişimci sayısını doğrudan etkiler. Dolayısıyla, Coşkun (2019)'da gösterildiği gibi denklem (5)'de yer alan modelde işgücü başına beklenen çıktı teknoloji seviyesini göstermek üzere $E\left(Y_{t-1}\right) / L_{t}=E X P Y_{t-1}=A\left(Z_{t-1}\right)$ ve benzer şekilde modelde teknolojiyi kaydıran faktör olarak $E C I_{t-1}=\ln \left(A\left(Z_{t-1}\right)\right)$ kullanılabilir. Böylece Ürün Uzayı yaklaşımı bu model ile Türkiye'de bilgi yayılım mekanizmasının işleyişindeki aksaklıların ve faktör birikiminin iktisadi büyüme ile ilişkisini birlikte değerlendirme imkânı vermiş olmaktadır. Bu durumda çalışmada tahmin edilecek denklemler aşağıdaki gibidir.

Model-a:

$\ln \left(y_{i t} / y_{i, t-1}\right)=\beta_{0}+\beta_{1} \ln y_{i, t-1}+\beta_{2} h_{i t}+\beta_{3} k_{i t}+\beta_{4} \ln E X P Y_{i, t-1}$

Model-b:

$\ln \left(y_{i t} / y_{i, t-1}\right)=\beta_{0}+\beta_{1} \ln y_{i, t-1}+\beta_{2} h_{i, t}+\beta_{3} k_{i, t}+\beta_{4} E C I_{i, t-1}$

$\mathrm{Bu}$ modellerde yer alan $i$ İBBS Düzey 2 bölgelerini ve $\mathrm{t}$ dönemi temsil etmek üzere, $\ln y_{t}$ terimi ise $t$ dönemindeki Türkiye İBBS Düzey 2 bölgelerinin logaritmik olarak kişi başına düşen reel GSYİH değeridir. $h_{t}, t$ 
dönemi beşerî sermaye seviyesi ve $k_{t}$ kamu alt yapı yatırımları olmak üzere, $\ln E X P Y_{t-1}, t-1$ dönemi ihracat sofistikasyonu ve $E C I_{t-1}$, ekonomik karmaşıklık endeksi değerleridir.

Rodriquez (2007) teknolojiyi kaydıran faktörlerin iktisadi büyüme ile arasındaki ilişkiyi araştıran çalıșmalarda modeldeki hata terimlerinin açıklayıcı değişkenlerle ilişkisinin bulunduğunu bu nedenle EKK ile tahmin edilen modellerin sapmalı sonuçlar verdiğini ileri sürüldügünden, EKK yöntemine dayalı tahmin edilen modellerde büyüme ve EXPY değişkenleri arasındaki ilişki hakkında yorum yapılamayacağı iddia edilmiştir. $\mathrm{Bu}$ nedenle, araç değişkenlerin yer aldığı iki aşamalı EKK, GMM, Dinamik GMM, Sistem GMM gibi yöntemlerin kullanılması gerektiği vurgulanmıştır.

Analizlerde dikkat edilmesi gereken nokta hem EXPY hem de bir önceki dönem kişi başına düşen gayri safi yurt içi hâsıla büyümesi ile ilişkili olduğundan hata teriminin açıklayıcı değişkenlerle ilişkili olmasıdır. Hata teriminin açıklayıcı değişkenlerle ilişkili olması ( $E(X / \varepsilon) \neq 0$ ) içsellik sorununa neden olabilmektedir. Bir diğer sorun ise EXPY değișkeninin bir önceki dönem kiși başına düşen gayrisafi yurt içi hâsıla, beșeri sermaye gibi faktörlerin bir fonksiyonu olmasıdır. Dolayısıyla, modeldeki diğer açıklayıcı değişkenlerle korelasyonu yüksektir. $\mathrm{Bu}$ sorunları dikkate almayan doğrusal tahmin modelleri kullanıldığında katsayılar sapmasızlık özelliğini yitirebilmektedir. Dahası parametre tahmincisi artık etkin (En küçük varyansa sahip) olmamaktadır. Bu durumda $\mathrm{t}$ dağılımları geçersiz olur. Diğer yandan kullanılan değişkenlerde mekânsal bağımlılığın

\footnotetext{
${ }^{1}$ Robust LM ve LR test sonuçları, Coşkun (2019:21) çalışmasında yer almaktadır. Yazarlardan talep edilmesi halinde gönderilebilir. LR test sonuçlarına göre model seçiminin nasıl yapılacağına ilişkin detaylar Coşkun (2019:118-121)'da yer almaktadır. Mekansal otokorelasyon sonuçları Coşkun (2019:78-79)'dan incelenebilir. İçsellik sorununa ilişkin Coşkun (2019:102)'deki açıklamalar dikkate alınmalıdır.
}

ve mekânsal heterojenliğin varlığı GaussMarkov varsayımlarının geçerliliğini yitirmesine neden olmaktadır. Bu durum alternatif tahmin yöntemlerini gerektirmektedir. $\mathrm{Bu}$ nedenle çalışmada tahmin edilmek istenen modeller, Sistem GMM, Mekânsal Maksimum Olabilirlik ile tahmin edilmiştir. Böylece, mekânsal bağımlılığın ve mekânsal heterojenliğin varlığı sınanarak modellere mekânsal etkinin dâhil edilmesi sonuçların güvenirliliğini arttıracaktır.

\section{BULGULAR}

$\mathrm{Bu}$ bölümde ise devletin alacağı önlemlerle yükselmesi hedeflenen ihracat sofistikasyonu ve ekonomik kompleksite endekslerinin Türkiye İBBS Düzey 2 bölgelerinde arzulanan iktisadi büyümeyi yaratıp yaratmadığına ilişkin ekonometrik analizlere yer verilmiştir. $\mathrm{Bu}$ amaçla ilk olarak mekânsal bağımlılığın uygun bir şekilde modellenmesinde kullanılan belirleme testlerinin ardından, sabit etkileri ve rassal etkileri dikkate alan modeller için mekânsal modelin belirlenmesine yönelik LR test sonuçları incelenmiştir ${ }^{1}$.

Tahmin edilecek uygun mekânsal etki modeline karar verildikten sonra ampirik bulgular kısminda Sistem-GMM, Sabit etkili (FE) Mekânsal MLE sonuçlarına yer verilmiştir. Blundell \& Bond (1998) ve Arellano \& Bover (1995) tarafından çerçevesi çizilen SistemGMM tahmincisinin Arellano \& Bond (1991) Fark- GMM tahmincisinden en önemli farkı etkinliği artırabilmek için düzeyde ve birinci farka bir regresyon sisteminin tahmin edilmesine dayanmasıdır². Böylece Fark-GMM tahmincisinin zayıf yönleri giderilmeye çalışılmıştır. Bu nedenlerle bu çalışmada MLE tahmincisine ek, dinamik modeller arasında yanlılığı daha düşük sonuçlar verecek olması

\footnotetext{
2 Yakınsama modelleri dinamik modeller olup, bu çalışmada kullanılan mekânsal etkileri dikkate alan tahminciler sapmalı sonuçlar vermektedir. Ancak, mekanlar arasındaki doğrudan ve dolaylı etkilerin ölçülmesine ve bu etkilerin ayrışımının önemli olduğu düşünüldügünden bu tahminciler de raporlanmıştır. Ardından dinamik tahminci olarak Sistem GMM sonuçları raporlanmıștır.
} 
nedeniyle Sistem GMM tahmincileri kullanılmıştır. Çalışmada Sistem GMM tahmincilerinde, $t$ istatistikleri sağlam (robust) değerler olup, kullanılan araç değişkenlerin aynı anda geçerliliği Hansen J testiyle sınanmıştır. Bu testte sınanan hipotez, tüm araç değișkenlerin ortak geçerli olduğudur. Dolayısıyla, Hansen J testinde sinanan hipotezin reddedilememesi GMM sonuçlarının geçerliliği için oldukça önemlidir. Sistem GMM tahmincilerinde Hansen $\mathrm{J}$ istatistiği tüm modeller için reddedilememiștir.

Tablo 2. Model-a Sonuçları

\begin{tabular}{|c|c|c|c|c|}
\hline Büyüme $\left(\mathrm{g}_{\mathrm{t}}\right)(2005-2014)$ & Sistem GMM & Sistem GMM & FE-MLE (SAR) & FE-MLE SEM) \\
\hline $\mathrm{GSYIH}_{\mathrm{t}-1}$ & $\begin{array}{l}-0,4 \\
(-0,50)\end{array}$ & $\begin{array}{l}-0,05 \\
(-0,57)\end{array}$ & \begin{tabular}{|l|}
$-0,24$ \\
$(-4,46)^{* * *}$
\end{tabular} & \begin{tabular}{|l|}
0,00 \\
$(-0,87)$
\end{tabular} \\
\hline$E X P Y_{t-1}$ & \begin{tabular}{|l|}
0,01 \\
$(0,16)$ \\
\end{tabular} & $\begin{array}{l}0,13 \\
(1,26)\end{array}$ & $\begin{array}{l}0,23 \\
(3,89)^{* *}\end{array}$ & $\begin{array}{l}-0,33 \\
(-6,48)^{* * *}\end{array}$ \\
\hline Beșeri Sermaye & $\begin{array}{l}0,08 \\
(1,65)^{*}\end{array}$ & \begin{tabular}{|l}
0,05 \\
$(1,15)$ \\
\end{tabular} & \begin{tabular}{|l}
0,02 \\
$(1,31)$ \\
\end{tabular} & \begin{tabular}{|l}
0,02 \\
$(1,45)$ \\
\end{tabular} \\
\hline Kamu Yatırımları & $\begin{array}{l}0,02 \\
(1,05) \\
\end{array}$ & $\begin{array}{l}0,01 \\
(0,71)\end{array}$ & $\begin{array}{l}0,00 \\
(-0,38)\end{array}$ & $\begin{array}{l}0,31 \\
(4,10)^{* * *}\end{array}$ \\
\hline Sabit & & $\begin{array}{l}-0,88 \\
(-3,55)^{* * *} \\
\end{array}$ & & \\
\hline $\mathrm{W}^{*}$ bağımlı değişsen & & & $\begin{array}{l}0,80 \\
(25,25)^{* * *}\end{array}$ & \\
\hline Mekânsal Hata & & & & $\begin{array}{l}0,82 \\
(26,30)^{* * *}\end{array}$ \\
\hline J-istatistiği & 25,92 & 25,93 & & \\
\hline J-istatistiği (olasılık) & 0,57 & 0,57 & & \\
\hline $\mathrm{AR}(2)$ test (p-value) & 0,37 & 0,11 & & \\
\hline Gecikme Sayısı & $2,1,1$ & $2,1,1$ & & \\
\hline
\end{tabular}

Ayrıca, Arellano \& Bond (1991) tarafından geliştirilen Arellano \&Bond (AR (\#)) testinde serilerde korelasyon yoktur hipotezi sınanmaktadır. $\mathrm{Bu}$ nedenle AR (2) test istatistiğinin olasılık değerinin yüksek olması, tahmincinin güvenilir sonuçlar vermesi açısından önemlidir. Bu çalışmada AR (2) test istatistiğinin olasılık değeri $0,05^{\prime}$ den küçük olması durumunda bağımlı değișkenin kullanılabilecek gecikme sayısı arttırılmıştır. Sorunun devam etmesi halinde bağımsız değişkenlerin kullanılabilecek gecikme sayısı arttırılmıştır. Bu şekilde uygun gecikme sayısı belirlenmiștir. Elde edilen modellerde AR (1) test istatistik değeri 0.05 'den küçük olsa da nihai karar AR (2) test istatistiğine göre verilmiștir. Model-a için yapılan analiz sonuçları Tablo 2'de yer almaktadır. Sistem-
GMM sonuçlarına göre EXPY, GSYIH ve kamu alt yapı yatırımlarının GSYIH içerisindeki payı \%5 önem düzeyinde anlamsız bulunmuştur. Ancak modeldeki mekânsal ilişkiler dikkate alındığında, FE-MLE (SEM) ve sabit terim içermeyen Sistem GMM sonuçlarına göre \%5 önem düzeyinde kamu alt yapı yatırımlarının GSYIH içindeki payı istatistiksel olarak anlamlı ve pozitiftir. Ayrıca, EXPY değerleri FE-MLE (SAR) modelinde $\% 5$ önem düzeyinde, FE-MLE (SEM) ve mekânsal Sistem-GMM tahmincilerinde \%1 önem düzeyinde istatistiksel olarak anlamlı ve pozitif katsayıya sahiptir. Mekânsal bağımlılık ilișkisinin modele dâhil edilmesiyle bölgelerde pozitif yönlü yayılma etkisi \%1 önem düzeyinde anlamlı ve pozitif bulunmuştur. 


\section{TUNCER - N. COSSKUN}

Model-a için FE-MLE (SAR) tahmincisi kullanılarak tahmin edilen katsayıların marjinal etkileri Tablo 3'de yer almaktadır. Modelde bilgi taşmalarının mekânsal bağımlılığa sahip olduğu sonucuna ulaşılmıştır. Dolayısıyla yeni verimlilik seviyesinde üretim yapan bölgedeki bilgi/beceri seti artışı, yalnızca sektörün bulunduğu bölgede değil, bölgenin sınır komşuluklarında da iktisadi büyümeye katkı sağlamaktadır. Aynı zamanda bir bölgedeki iktisadi büyümedeki artış bölgenin kendi beşerî sermaye seviyesindeki, kamu alt yapı yatırımlarındaki ve EXPY değişkenindeki artıştan kaynaklanabileceği gibi, komşu bölgelerdeki beșerî sermaye seviyesi, kamu alt yapı yatırımları ve EXPY değişkenindeki artıştan kaynaklanabilmektedir. FE- MLE (SAR) modelinde EXPY değerindeki \%1'lik artış iktisadi büyümeyi \%1,22attırmaktadır. Bir bölgenin komşularındaki EXPY değerinin ortalamasındaki \%1'lik artış, bölgenin büyümesini $\% 0,92$ artmaktadır. Bir bölgenin kendi EXPY değişkenindeki \%1'lik artış, bölgenin kendi büyümesini $\% 0,30$ arttırmaktadır. Model-b'nin tahmin sonuçlarına göre Mekânsal bağımlılığın dikkate alındığı modellerde ECI değerleri \%10 önem düzeyinde istatistiksel olarak anlamlı değildir. Tablo 4'de yer alan sonuçlara göre ECI değeri yalnızca sabit terimin de modelde dahil edildiği Sistem-GMM için \%10 önem düzeyinde istatistiksel olarak anlaml ve pozitif bulunmuştur. GSYİH katsayısının negatif olması bölgesel yakınsamanın varlığına işaret etmektedir. Elde edilen bulgular literatürle uyumludur. GSYIHH katsayısının mekânsal etkileri dikkate alan tahmincilerle yapılan analiz sonuçlarına göre negatif ve $\% 5$ istatistiksel önem düzeyinde anlamlı bulunması, bölgesel yakınsamanın varlığına işaret etmektedir. Ayrıca, mekânsal etkiler dikkate alındığında, bölgenin büyümesine kendisindeki ihracat sofistikasyonu artışından çok komşularındaki ihracat sofistikasyonu seviyesindeki artışın daha fazla katkıda bulunduğu ve Yeni Ekonomik Coğrafya yaklaşımına göre yayılma etkisinin yığılma etkisinden daha güçlü olduğu sonucuna ulaşılmıştır. Böylece bölgeler komşularının bilgi/beceri seti arttıkça daha hızlı büyümektedir. Bu durum aynı zamanda Evrimci Ekonomik Coğrafya yaklaşımında iddia edildiği gibi bilginin mekânsal yayılmasının (diffusion) sadece mekân içerisinde gerçekleşmediği, büyümenin gerçekleștiği merkezin yanındaki şehirlere ve yerlere de yayıldığını göstermesi açısından önemlidir. Analizlerimizde dikkat çeken bir diğer olgu Türkiye'nin dünya ortalamasının üstünde çeşitlenmeye sahip bir ülke olmasına rağmen Jacobs dışsallıklar ve büyüme arasındaki mekanizmanın işlemediğine ilişkin bulgulardır. Bunun en önemli sebebi Türkiye ekonomisinin verimliliği düşük alanlarda uzmanlaşmasının yarattığı düşük bilgi/beceri seti olabilir. Analiz sonuçları konuyla ilgili literatürde yer alan diğer çalışmalarla tutarlıdır. Bununla birlikte, kamu alt yapı yatırımlarının katsayısının anlamsız olması, izlenen devlet politikalarının bölgelerin optimal üretim yapısının evrimini destekleyecek yönde olmadığına işaret etmektedir. Ayrıca, Türkiye'nin mevcut üretim yapısı sahip olduğu faktör teçhizi ile örtüşmeyen optimalin altında bir denge üretim seviyesinde bulunduğundan mevcut üretim yapısı arzulanan iktisadi büyümeyi yaratamamaktadır. $\mathrm{Bu}$ bağlamda, Evrimci Ekonomik Coğrafya yaklaşımının ürün yaşam döngüsüne göre yayılma etkisi ile ürünlerin standart hale gelmesi arasında güçlü bir ilişki bulunmaktadır. Merkezde nitelikli ürün üretilirken, zamanla standartlaşan ürün çevredeki diğer bölgelere yönelir. Taymaz, Voyvoda \& Yılmaz (2011)'a göre, Türkiye küresel değer zincirlerine kendi ihtiyaçları ya da politikaları doğrultusunda aktif bir biçimde eklemlenmemiştir. Bu eklemlenme gelişmiş ülkelerin kendi ihtiyaçlarını karşılamada üretim maliyetlerini düşürmek istemesi nedeniyle, diğer ülkelere kaydırılan üretim aşamalarına pasif olarak eklemlenme biçiminde gerçekleşmiştir. $\mathrm{Bu}$ durum Türkiye'nin gelişmiş ülkelerle arasındaki farkın kapanmasını zorlaştıran bir unsurdur. Erkan v.d (2007), Türkiye'nin ithal ikameci üretim yapısından, ihracata dayalı büyüme stratejisine 
yöneldiğini ancak emek yoğun sektörlerde uzmanlaştığını iddia etmektedir. Bununla birlikte, Coşkun, Lopcu \& Tuncer (2018) Türkiye'nin çeşitliliği yüksek bir ülke olmasına rağmen, verimliliği düşük ürün gruplarında çeşitlendiği için bilgi/beceri setinin de olması gereken düzeyin altında kaldığını bu nedenle ürün çeşitlenmesine, sağlıklı bir iktisadi büyüme sürecinin eșlik etmediğini ileri sürmüştür. Taymaz, Voyvoda \& Yllmaz (2011) ise Türkiye'nin teknolojisi standartlaşmıș, düşük maliyet temelinde rekabetçi olunabilecek ürünlerde uzmanlaştığına işaret etmiștir. Bu durum, Türkiye'nin merkez ülkelerin ürettikleri ürünlerden çok, düşük maliyet ve lojistik avantajı nedeniyle gelişmiș ülkelerde artık teknolojisi standart hale gelmiş ürünlerin çevre ülke olarak Türkiye'ye kaymasıyla üretimine devam ettiğini göstermektedir.

Tablo 3. Model-a FE MLE (SAR) Ayrıștırılmış Katsayılar

\begin{tabular}{|c|c|c|c|}
\hline Model-3 & Katsayı & Alt Sinır(05) & Üst Sınır (95) \\
\hline \multicolumn{4}{|c|}{ Doğrudan Etki } \\
\hline GSYİH$_{\mathrm{t}-1}$ & $\begin{array}{l}-0,32 \\
(-4,56)^{* * *}\end{array}$ & $-0,45$ & $-0,19$ \\
\hline$E X P Y_{t-1}$ & $\begin{array}{l}0,30 \\
(3,98)^{* * *}\end{array}$ & 0,16 & 0,45 \\
\hline \multicolumn{4}{|c|}{ Dolaylı Etki } \\
\hline GSYİH$_{\mathrm{t}-1}$ & $\begin{array}{l}-0,95 \\
(-3,40)^{* * *}\end{array}$ & $-1,60$ & $-0,48$ \\
\hline$E X P Y_{t-1}$ & $\begin{array}{l}0,92 \\
(3,12)^{* * *}\end{array}$ & 0,41 & 1,58 \\
\hline \multicolumn{4}{|c|}{\begin{tabular}{|l|} 
Toplam Etki \\
\end{tabular}} \\
\hline GSYİH $_{\mathrm{t}-1}$ & $\begin{array}{l}-1,27 \\
(-3,76)^{* * *}\end{array}$ & $-2,00$ & $-0,69$ \\
\hline$E X P Y_{t-1}$ & $\begin{array}{l}1,22 \\
(3,39)^{* * *}\end{array}$ & 0,58 & 2,01 \\
\hline
\end{tabular}

Tablo 4. Model-b Sonuçları

\begin{tabular}{|c|c|c|c|c|}
\hline Büyüme $\left(\mathrm{g}_{\mathrm{t}}\right)(2005-2014)$ & Sistem GMM & Sistem GMM & FE-MLE (SAR) & FE-MLE (SEM) \\
\hline GSYIH $_{\mathrm{t}-1}$ & $\begin{array}{l}-0,03 \\
(-1,55) \\
\end{array}$ & \begin{tabular}{|l|}
0,02 \\
$(0,49)$ \\
\end{tabular} & $\begin{array}{l}-0,04 \\
(-0,22)^{* * *}\end{array}$ & \begin{tabular}{|l|}
$-0,19$ \\
$(-4,92)^{* * *}$
\end{tabular} \\
\hline $\mathrm{ECI}_{\mathrm{t}-1}$ & $\begin{array}{l}0,007 \\
(0,40)\end{array}$ & $\begin{array}{l}0,002 \\
(0,07)^{*}\end{array}$ & $\begin{array}{l}-0,001 \\
(-0,02)\end{array}$ & $\begin{array}{l}0,002 \\
(0,34) \\
\end{array}$ \\
\hline Beșeri Sermaye & $\begin{array}{l}0,07 \\
(1,59)\end{array}$ & $\begin{array}{l}0,04 \\
(0,85) \\
\end{array}$ & $\begin{array}{l}0,003 \\
(1,95)^{* *}\end{array}$ & $\begin{array}{c}0,01 \\
(1,59) \\
\end{array}$ \\
\hline Kamu Yatırımları & $\begin{array}{l}0,02 \\
(1,64) \\
\end{array}$ & $\begin{array}{l}0,02 \\
(1,49) \\
\end{array}$ & $\begin{array}{l}0,003 \\
(0,84)^{*}\end{array}$ & $\begin{array}{l}-0,0006 \\
(-0,16) \\
\end{array}$ \\
\hline Sabit & & \begin{tabular}{|l|}
$-0,39$ \\
$(-1,37)$ \\
\end{tabular} & & \\
\hline $\mathrm{W}^{*}$ bağımlı değişken & & & $\begin{array}{c}0,78 \\
(22,69)^{* * *} \\
\end{array}$ & \\
\hline Mekânsal Hata & & & & $\begin{array}{l}0,81 \\
(26,59)^{* * *}\end{array}$ \\
\hline J-istatistiği & 25,92 & 25,88 & & \\
\hline J-istatistiği (olasılık) & 0,57 & 0,57 & & \\
\hline AR(2) test (olasılık) & 0,43 & 0,40 & & \\
\hline Gecikme Sayısı & $2,1,1$ & $2,1,1$ & & \\
\hline
\end{tabular}




\section{TUNCER - N. COSSUN}

\section{DEĞERLENDİRME}

Elde edilen bulgulara göre, mekânsal etkiler dikkate alındığında, Türkiye İBBS Düzey 2 bölgeleri arasında yakınsamanın belli ölçülerde geçerli olduğu anlaşılmaktadır. Türkiye'de, bölgelerin iktisadi büyümesine bölgenin kendi ihracat sofistikasyonu artışından çok komşularındaki ihracat sofistikasyonu seviyesindeki artış katkıda bulunmaktadır. Bu bulgu, Evrimci Ekonomik Coğrafya yaklaşımına göre yayılma etkisinin yığılma etkisinden daha güçlü olduğuna işaret etmektedir. Bu durum, Türkiye'deki bölgeler arası gelir farklılıklarının, yayılmayı destekleyici politikalarla, azaltılabileceğini göstermesi açısından önemlidir. Merkez olarak belirlenen bölgelerde yenilik ve yeni ürünlerin gelişmesinde etkili rol alan "keşif maliyeti bilgisinin" yarattı̆̆ dışsallıkların desteklenmesi, merkezde yer alan daha düşük teknolojili ürünlerin üretiminin çevre bölgelere yayılmasına neden olacaktır. Ayrıca devlet sanayi politikalarını bölgelerin karşılaştırmalı üstünlüklerini ve faktör teçhizindeki kısıtları değerlendirerek belirlediğinde yayılma etkisiyle çevre bölgelerde de optimal üretim yapısına doğru yapısal dönüşüm hızlanabilecektir. Türkiye ekonomisinin verimliliği düşük alanlarda uzmanlaşmış olması, Türkiye'de bilgi/beceri seti düzeyinin de gereken seviyenin altında kalmasıyla sonuçlanmış ve bu durum bilgi yayılım mekanizmalarını etkileyerek yapısal dönüşümün yavaş olmasına yol açmış görünmektedir. Analiz sonuçlarına göre, EXPY tüm modellerde anlamlı ve beklendiği gibi pozitif katsayıya sahiptir. Dolayısıyla, Türkiye Düzey 2 bölgelerinin sofistikasyonu yüksek ürünlerde uzmanlaşması ve sektör içi verimlilik artışları iktisadi büyümeyi desteklemektedir. Ancak Ekonomi Kompleksite Endeksi (ECI) negatif ve anlamsız katsayıya sahiptir. ECI ile birlikte kamu alt yapı yatırımlarının katsayısının da anlamsız olması, devlet politikalarının bölgelerin faktör teçhizine uygun olan ideal uzmanlaşma yapısına denk düșen sektörleri destekler nitelikte olmadığını göstermektedir. Elde edilen bu sonuçlar, Türkiye Düzey 2 bölgelerinin optimalden uzak bir denge üretim seviyesinde olduğunu ve bu durumun da mevcut üretim yapısının iktisadi büyümeyi desteklemesini zorlaştırdığına işaret etmektedir. Yatırım önceliklerinin bölgelerin sahip olduğu cari faktör teçhizine uygun faaliyetlere doğru yönlendirilmesi gelecekte büyüme ve verimlilik üzerinde pozitif etkiler yaratacaktır. Sonuç olarak, Türkiye ekonomisinde sektörel politika önlemleri belirlenirken, üretken bilgi/beceri setini daha üst düzeye taşıma potansiyeline sahip sektörler desteklenmelidir. Dolayısıyla bu noktada devlete, yerel yönetimlere ve yerel kalkınma inisiyatiflerine düşen rol her bir iktisadi bölge için ilgili bölgenin faktör teçhizi ile örtüşen (optimali sağlayan) hedef sektörleri doğru bir şekilde belirlemek ve bu sektörler için teşvik edici önlemler alarak yapısal dönüşümü hızlandırmaktır.

\section{KAYNAKÇA}

Anselin, L. (1988a). Spatial econometrics:methods and models. Kluwer Academic, Dordrecht

Anselin, L. (1988b). Lagrange multiplier test diagnostics for spatial dependence and spatial heterogeneity. Geographical Analysis, 20(1), 117.

Arellano, M., \& Bond, S. (1991). Some tests of specification for panel data: Monte Carlo evidence and an application to employment equations. The Review of Economic Studies, 58(2), 277-297.

Arellano, M., \& Bover, O. (1995). Another look at the instrumental variable estimation of error-components models. Journal of Econometrics, 68(1), 29-51

Arıcıoğlu, E., Coşkun, N. Tuncer, İ. (2017). Türkiye'de IBBSS Düzey 2 bölgelerinin büyüme dinamikleri ve ekonomik karmaşıklık analizi-4: Tasarruf, Sürdürülebilir Büyüme ve Teknolojik 
Gelişme içinde. Editör: Erdoğdu, O.S., Dinç, D.T., Attar, M.A., ISBN: 978-975-8958-18-4, İmaj Yayınevi, Ankara, Türkiye.

Blundell, R., \& Bond, S. (1998). Initial conditions and moment restrictions in dynamic panel data models. Journal of Econometrics, 87(1), 115-143.

Boschma, R. A., \& Frenken, K. (2003). Evolutionary economics and industry location. Review of Regional Research,23(2), 183-200.

Boschma, R. A., \& Frenken, K. (2006). Applications of evolutionary economic geography. K. Frenken, (ed.). Applied Evo2 lutionary Economics and Economic Geography.

Boschma, R., \& Frenken, K. (2009). Some notes on institutions in evolutionary economic geography. Economic Geography, 85(2), 151158.

Boschma, R., \& Frenken, K. (2010). The spatial evolution of innovation networks. A proximity perspective-3. The handbook of evolutionary economic geography içinde Geography (3-43). (No. 1001). Utrecht University.

Coşkun, N., \& Tuncer, İ. (2016). Ürün uzayı yaklaşımı göstergeleri bağlamında mekansal bağımlılığın Türkiye İBBS Düzey 2 bölgeleri için sinanması. Balkan Journal of Social Sciences/Balkan Sosyal Bilimler Dergisi, 5.

Coşkun, N.; Tuncer, İ.; Lopcu, K. (2018). The Economic Complexity Approach to Development Policy: Where Turkey Stands in Comparison to OECD plus China? Topics in Middle Eastern and North African Economies 20 (1).

Coşkun, N. (2019). Ürün Uzayı Yaklaşımı: Türkiye IBBS Düzey 2 Bölgeleri için bir Uygulama (Doktora Tezi, Mersin Üniversitesi Sosyal Bilimler Enstitüsü, Mersin).

Dış Ticaret Müsteşarlığı, (2011). İl İl Dış Ticaret Potansiyeli.

Elhorst, J. P. (2003). Specification and estimation of spatial panel data models. International Regional Science Review, 26(3), 244-268.

Elhorst, J. P. (2010). Applied spatial econometrics: raising the bar. Spatial Economic Analysis, 5(1), 9-28.

Erkan H., Uysal Y, Erkan C., Çetinkaya M., Şanlısoy S., Bașer N. E., Afşar K. E., Aydın Ü., (2007 b), "Türkiye İçin Bilgi Bazlı Sürdürülebilir Yenilikçi Sanayileşme Stratejisi", EGİAD Yayınları, İzmir.

Frenken, K., \& Boschma, R. A. (2007). A theoretical framework for evolutionary economic geography: industrial dynamics and urban growth as a branching process. Journal of Economic geography, 7(5), 635-649.

Frenken, K., Oort, F., Verburg, T., \& Boschma, R. (2004). Variety and regional economic growth in the Netherlands (No. 0502). Utrecht University, Economic Geography içinde.

Hansen, L. P. (1982). Large sample properties of generalized method of moments estimators. Econometrica: Journal of the Econometric Society, 1029-1054.

Hausmann, R., Hidalgo, C. A., Bustos, S., Coscia, M., Simoes, A., \& Yildirim, M. A. (2011). The atlas of economic complexity: Mapping paths to prosperity. Mit Press.

Hausmann, R., Hwang, J., \& Rodrik, D. (2007). What you export matters. Journal of economic Growth, 12(1), 1-25.

Hidalgo, C. A., \& Hausmann, R. (2009). The building blocks of economic complexity. proceedings of the national academy of sciences, 106(26), 10570-10575.

Islam, N. (1995). Growth empirics: a panel data approach. The Quarterly Journal of Economics, 110(4), 1127-1170.

Lin, J. Y. (2011). From flying geese to leading dragons: New opportunities and strategies for structural transformation in developing countries. Global Policy, 3(4), 397-409.

Lin, J. Y. (2012). New structural economics: a framework for rethinking development. The World Bank Research Observer, 26(2), 193-221. 


\section{TUNCER - N. COŞKUN}

Mankiw, N. G., Romer, D., \& Weil, D. N. (1992). A contribution to the empirics of economic growth. The Quarterly Journal of Economics, 107(2), 407-437.

Pyka, A., Kuştepeli, Y., \& Hartmann, D. (Eds.). (2016). International innovation networks and knowledge migration: The german-turkish nexus. (Erişim Adresi: Routledge.https://books.google.com.tr/books ?hl=en\&lr=\&id=jKSuDAAAQBAJ\&oi=fnd \&pg= PT58\&dq=hausmann+rodrik+moving++to+ad jent+\&ots=JuYUi8QKN\&sig=YCz6cesx2ptdqc WzXU3wP3N1C6w\&redir_esc=y\#v=onepage \& $\mathrm{q}=$ Turkey\&f=false)

Rodríguez, F. (2007). Cleaning up the kitchen sink: growth empirics when the world is not simple. Mimeographed, Wesleyan University, Connecticut.

Solow, R. (1957). Technical change and the aggregate production function. The Review of Economics and Statistics, 39(3), 312-320. doi:10.2307/1926047

Sosyal Güvenlik Kurumu (SGK), Sigorta Primleri Genel Müdürlüğü. (Erişim Tarihi: 01.01.2016).

T.C Kalkınma Bakanlığı, (2014). Imalat sanayiinde dönüşüm özel ihtisas komisyonu raporu. Onuncu Kalkınma Planı (2014-2018), Ankara.

T.C Kalkınma Bakanlığı, (2017). İl bazında yatırımlar. (Erişim Tarihi: 05.05.2017) (Erişim Adresi:

http://www2.kalkinma.gov.tr/kamuyat/iloze t.html

T.C Zafer Kalkınma Ajansı ve Türkiye Ekonomi Politikaları Araștırma Vakfi (Tepav). (2014). TR 33 Bölgesi'nin üretim yapısının ve düzeyinin tespiti ve analizi. Strateji belgeleri.

Taymaz, E., Voyvoda, E. and Yllmaz, K. (2011). Uluslararası üretim zincirlerinde dönüşüm ve türkiye'nin konumu. TÜSİAD-KOÇ University Economic Research Forum, İstanbul, (Erişim Adresi: http://eaf.ku.edu.tr/sites/eaf.ku.edu.tr/files/ eaf_rp_1101.pdf.)
Tuncer, İ., Lopcu, K., Coşkun, N., \& Arıcıoğlu, E. (2017) Türkiye bölgelerinde yapısal değişim: kümeleme ve ekonomik karmaşılklı bağlamında öneriler. Ekonomi Bilimleri Dergisi, 9(2), 59-74.

Türkiye İstatistik Kurumu (TÜİK). İşgücü istatistikleri. (Erişim Tarihi: 05.05.2017)

Türkiye İstatistik Kurumu (TÜİK). Nüfus ve demografi. (Erişim Tarihi: 05.05.2017)

Türkiye İstatistik Kurumu (TÜİK). Ulusal hesaplar. (Erişim Tarihi: 05.05.2017)

Yildirim, M. A. (2018). Kompleksite ve ürün uzayi metodolojisiyle Türkiye. In $\mathrm{Koç}$ University-TUSIAD Economic Research Forum Working Papers (No. 1806). Koc UniversityTUSIAD Economic Research Forum. 